4. Олешков М.Ю. Моделирование коммуникативного процесса: монография. Нижний Тагил: Нижнетагильская гос. соц.-пед. академия [и др.]., 2006. 336 с. URL: http://rudocs.exdat.com/docs/index-48183.html (дата звернення: 18.03.2020).

5. Панченко Е.И. Лингвистика сжатого текста (на материале современного русского языка): дис. ... д-ра филол. наук: 10.02.02. Донецк, 1998. 380 с.

6. Панченко Е.И. Сжатый текст: текст современности и будущего. Русский язык: исторические судьбы и современность: сборник тезисов I Международного конгресса исследователей русского языка. М., 2001. C. $286-287$.

7. Солганик Г.Я. Автор как стилеобразующая категория публицистического текста. Вестник Московского университета. Серия 10. Журналистика. № 3. Москва: Изд-во МГУ, 2001. С. 75.

8. Die wichtigsten Social Media Trends für 2020. URL: https://www.wuv.de/tech/die_wichtigsten_social_media_trends_fuer_ 2020 (дата звернення: 18.01.2020).

DOI https://doi.org/10.30525/978-9934-26-073-5-2-39

\title{
СЕМАНТИЧНІ ІННОВАЦЙНІ ОДИНИЦІ В ЗАГОЛОВКАХ ПЕРІОДИЧНИХ УКРАЇНСЬКОМОВНИХ ІНТЕРНЕТ-ВИДАНЬ
}

\author{
Бойчук М. В. \\ кандидат філологічних наук, \\ дочент кафедри права \\ Івано-Франківської філії Відкритого міжнародного університету \\ розвитку людини «Україна»
}

\section{Бойчук В. М.}

кандидат філологічних наук, дочент, завідувач кафедри сочіально-гуманітарних дисциплін Прикарпатського факультету Начіональної академії внутрішніх справ м. Івано-Франківськ, Україна

Динамічні зміни в лексиці сучасної української мови зумовлені різними чинниками, зокрема й активними процесами у межах лінгвосистеми з огляду на розширення функціоналу мови. Результатами перетворень значною мірою $є$ семантичні трансформації лексичного 
складу, що віддзеркалюють через ментальну призму суспільну онтологію носія мови.

Яскравим прикладом універсальної природи мови слугує поповнення лексикону засобів масової інформації, які сьогодні все частіше набувають електронних версій. Звідси - аксіомою стає твердження про те, що, власне, ЗМІ $є$ тією сферою лінгвального функціонування, де лексичні засоби мови постійно оновлюються й удосконалюються.

Мова преси безпосередньою і оперативною реакцією на суспільні зміни, що втілюються у лексико-семантичних перетвореннях у системі мови, демонструє ієрархію і поліфункціональність різноструктурних процесів, що відбуваються у довколишньому світі, а також детермінує значущі зміни у лексичному корпусі. А тому виникнення неологізмів, запозичення та інтеграція іншомовних лексем, формування семантичних дериватів тривають безперервно.

Відомо, що семантична деривація має місце у разі використання уже відомого слова (його зовнішньої форми) для номінації нового об'єкта навколишньої дійсності. Це - явище вторинної номінації, що корелює 3 принципом економії мовних засобів, коли немає інтенсивного приросту одиниць плану вираження, а номінативна діяльність спрямовується у русло вторинної номінації, або ж до семантичної трансформації наявних засобів найменування.

В українському мовознавстві явища семантичної деривації різнобічно висвітлено в роботах О. Стишова, Л. Струганець, К. Ленець, I. Самойлової, Н. Тропіної, Т. Бевз та інших. Однак постає необхідність опрацювання подібних процесів у заголовках періодичних інтернетвидань, що є метою пропонованої наукової студії. Відповідно об'єктом дослідження обрано семантичні неологізми у заголовках періодичних інтернет-видань.

Специфіка творення вказаних неологічних одиниць зумовлена тим, що для реалізації авторської інтенції маємо простір тільки на рівні значення слова, форма ж - незмінювана. Тому авторський хист визначається вмінням приєднати готову форму, для якої характерна власна когнітивна фоновість і смислова асоціативність, до нового поняття, що згідно з комунікативною потребою має бути названо, а також майстерністю знайти мотиваційні точки дотику. Наприклад, з 24 серпня США почнуть карати Украӥну за піратство - «умисне незаконне використання об'єктів права інтелектуальної власності...» (УП, 22.08.01); Тимошенко: у Раді знову скуповують «тушок» (ФП, 28.03.11); «Плиточникам» з Майдану пред'явили звинувачення - 
«група осіб, що звинувачується у пошкодженні плитки на Майдані Незалежності під час податкових протестнрих акцій» (УП, 04.03.11).

Семантична деривація, в результаті якої виникають інновації вказаного типу, може охоплювати різні одиниці. У таких процесах зазвичай домінує образологіка носія мови. Досліджено, що до таких процесів залучаються одиниці неоднорідної структурної, дериваційної і смислової природи:

1) розмовні слова: Украӥна звернулась до «Венеційки» щуодо законопроєктів про обрання членів ВРП (УП, 29.03.21) - Венеційська комісія;

2) жаргонізми: иирка - «цирока коаліція» (УП, 12.05.09). Пор.: ширка - це сленгова назва у наркоманів дози ацетилійованого опію. Варто зауважити, що значну роль у процесі творення цього неологізму відіграє співзвучність компонентів: иирока коаліція > иирка;

3) етранжизми (запозичені лексичні одиниці): «Регіони» - «Партія регіонів» (УП, 12.05.09); у тому числі - й екзотизми: «сісста» - «зміна графіку роботи у зв'язку зі спекою» (УП, 07.06.11), шериф - «дільничний інспектор» (ЛП, 22.10.09);

4) історизми: гонець - «новий посол Росії в Україні» (УП, 23.10.09); Сюди зараховуваємо і назви історичних подій: Ющееко за день до Ватерлоо - «відставка уряду» (УП, 23.04.01);

5) архаїзми: «сідалище» - «вертолітний майданчик для президента Віктора Януковича в Каневі» (УП, 11.02.11);

6) професіоналізми: За два місяці до обшуків на "ПВК Семенченка» ї̈ «здав» один із членів (УП, 30.03.21); У Росії вважають, щуо США захочуть «відтоптатися на ӥхніх виборах» (УП, 30.03.21);

7) терміни: «дипломат» - «затриманий на словаџько-украӥнському кордоні украӥнець, який мав при собі дипломатичний паспорт» (УП, 25.08.01); мажсор - «син заможних і впливових батьків» (ЛП, 23.05.09);

8) лексеми 3 числовою семантикою: «Нормандська трійка»: в ОП наголошують, що без України рішення щодо Донбасу неможливі (нормандський формат) (УП, 31.03.21).

Крім іменників, до процесів семантичної деривації залучаються слова інших частин мови: За 2 тижні банки видали «теплих кредитів» на 84 мільйони (УП, 13.04.21) (енергоефективні заходи).

Деякі семантичні неологічні деривати демонструють активність щодо входження в узус. Так, нове значення лексеми колядувати («одержувати незаконним шляхом»), запроваджене в обіг сумнозвісним суддею, починає розширює межі свого вживання: наколядували барсетку 
(ЛП, 25.01.11). Пор. також і фіксацію У Запоріжжі підприємйі збирають гроші на київський Майдан (УП, 25.11.10).

Найпоширеніший спосіб перенесення - це метафора. Автори семантичних неологізмів використовують найрізноманітніші зближення: Венедіктова розповіла представникам Держдепу $i$ повіреній США про «кадрове перезавантаження" (УП,15.04.21) - (кадрове перезавантаження прокуратури - атестації). Зеленський поки не знає, з ким в Украӥни більше «хімії» - Трампом чи Байденом (УП,16.04.21).

Рідше використовуються метонімія: Зеленський перед візитом в Париж просить ЄС $i$ НАТО «узаконити шлюб» 3 Україною (УП,16.04.21 (заклик прийняти Украӥну до ЄС та НАТО), «Найгірший спалах»: Київ відкриває для COVID-хворих пологові й дитячі лікарні (УП, 08.04.21).

Семантична деривація застосовується і щодо лексикалізованих сполучень: «2 в 1»- «поєднання посади першого секретаря політради з посадою голови СПУ» (УП, 13.11.07), і щодо сталих висловів: «Руки геть від Украӥни»: найбільша фракиія Свропарламенту попередила Путіна про наслідки (УП, 12.04.21); На Прикарпатті троє кандидатів ідуть ніс у ніс - екзитпол (УП, 28.03.21); На Донбасі хочуть створити "пояс успішності» - Рєзников (УП,28 .03.21); "Світає і смеркає, незалежно від законів": Стефанчук лобіює скасування переведення годинників (УП,26.03.21).

У процесах семантичної деривації часто активну роль відіграє форма вихідної одиниці: Трейдер Веревського, комбінати Ахметова та "донька» американської агрокомпанії отримали найбільще відшкодування ПДВ за березень (УП, 17.04.21). ДП «Сантрейд»- дочірнє підприємство американської агропромислової компанї̈ Bunge.

Таким чином, студіювання інновацій у заголовках інтернет-видань $\epsilon$ актуальним завданням науки про мову, оскільки уможливлює не лише висвітлення і розуміння активних словотворчих тенденцій у лексиконі української мови, зумовлених як екстралінгвальними, так й інтралінгвальними чинниками, а й усвідомлення глибинних ментальних процесів, що генерують картину світу українця і iї національнолінгвальну презентацію відповідно до специфікації мовної системи.
Література:
1. УП - Українська правда http://www.pravda.com.ua/news
2. ФП - Форпост http://www.4post.com.ua
3. ЛП - Львівська пошта http://www.lvivpost.net 